\title{
RESENHA
}

SERNA, Justo; PONS, Anaclet. La historia cultural. Madrid: Ediciones Akal, 2005, p. 249

Teresa Malatian*

A história cultural experimentou vertiginoso crescimento no Brasil nas últimas décadas e alcançou o estatuto de área das mais promissoras da pesquisa histórica, a ponto de se tornar área de concentração de diversos programas de estudos de pós-graduação. Nada mais oportuno, pois, que a leitura de um livro como o de Justo Serna e Anaclet Pons, professores especialistas em História Social e Cultural da Universidade de Valencia, Espanha. Entre suas obras, destacam-se o estudo La ciudad extensa (1992) sobre os burgueses no século XIX, e diversos ensaios de historiografia, a exemplo de Cómo se escribe la microbistoria (2000).

La historia cultural: autores, obras, lugares, publicado em 2005, aborda as diferentes possibilidades desse campo historiográfico e contribui para a compreensão da metodologia que vem sendo utilizada pelos pesquisadores que percorrem essa vertente potencialmente inovadora da Historiografia. Para isso, os autores partem em busca da

* Prof. Adjunto do Departamento de História da Faculdade de História, Direito e Serviço social - UNESP, campus de Franca. Rua Major Claudiano 1488, CEP 14400690 - Franca, SP, email-tmalatian@uol.com.br.

Anos 90, Porto Alegre, v. 14, n. 25, p.223-227, jul. 2007 
gênese da definição do conceito de cultura no interior de um diálogo interdisciplinar entre História e Antropologia, e voltado para a distinção entre a natureza e a criação humana que lhes permite afirmar ser a cultura "dispositivo que nos aleja de la naturaleza" (p. 6). Conceptualização feita, abre-se um amplo leque de possibilidades de construção de objetos da história cultural, a se ocupar de códigos e convenções, instrumentos e regras, significados e prescrições, que permitem ao historiador um manancial riquíssimo de temas a serem trabalhados com as ferramentas de um método que se constrói na interface da disciplina com as ciências humanas.

Idêntico percurso, também em perspectiva historiográfica, permite aos autores desvendar, na pletora de obras que abordam a história cultural, temas e métodos mais significativos que caracterizam o campo na segunda metade do século XX. Melhor dizendo, o fio condutor desse livro é dado pela "genealogia do campo", a qual permite a percepção da vitalidade do recorte analítico e as inumeráveis dimensões de possibilidades de construção do objeto. Para alcançá-la, é rastreado o "colégio invisível" dos autores que se sobressaem nos estudos de história cultural, num percurso de filiações e interdependências convergentes para a construção de um campo metodológico tramado em dimensões intercontinentais e muito distante de um paradigma unitário.

Os anos 1970 constituem, nessa perspectiva, um marco na formação de uma rede textual que agrega Roger Chartier, Carlo Guinzburg, Peter Burke e Robert Darnton, e tem como figura central Natalie Zemon Davis. As práticas acadêmicas de interlocução entre pares são esmiuçadas pelos autores desse livro em busca dos fios da trama da rede nem sempre totalmente invisível, porém agregadora de perspectivas analíticas e temáticas inovadoras desse "modo de fazer" que compartilha a fragmentação da História com os herdeiros divididos de Braudel.

Constitui excelente contribuição o tratamento historiográfico desse colégio e seus desdobramentos na busca de modos de construção 
da narrativa da cultura, vista em perspectiva histórica. Não mais extensas obras, centradas num único tema, no formato de tese acadêmica, e sim ensaios e fragmentos reunidos em volume, autônomos porém entrelaçados e que, em relação dialógica, constituem a característica textual de disseminação do objeto, fraturado em operação historiográfica devedora de Walter Benjamin e Wittgenstein. A complexidade sucessiva da abordagem, a multiplicação de referências a interlocutores internos, a reescrita contínua em resposta a múltiplos auditórios permitem a conexão entre os textos através de uma idéia mais geral que lhes serve de vínculo secreto e iluminação. Estratégia que reforça o conceito de cultura como código, marco, repertório de possibilidades.

Ao desvendar o colégio invisível dos autores e obras relevantes para a História cultural, o livro detém-se na identidade acadêmica e experiência de vida que constituiria o elemento forte de ligação entre os historiadores. Para isso, importância decisiva é atribuída aos anos de formação desses pesquisadores no pós-Segunda Guerra Mundial e à maturidade por eles alcançada na década de 1960, período marcado pela "americanização" da cultura e pela difusão do materialismo histórico no mundo acadêmico europeu. Com esse pressuposto, foi possível aos autores da obra em análise construir uma rede, tendo como epicentro a figura aglutinadora de Natalie Zemon Davis, situada na intersecção entre os expoentes da historiografia marxista britânica em sua vertente cultural e a historiografia francesa.

Serna e Pons apresentam um recorte da vertente do marxismo britânico de R. Hoggart, R. Williams, E. P. Thompson e E. Hobsbawm, ressaltando sua contribuição para o "novo materialismo cultural", centrado na história from below e na cultura popular, nas experiências e tradições do povo comum que ocuparam os pesquisadores da universidade de Oxford.

Em Natalie Z. Davis essa proposta encontra ressonância no estudo do menu peuple e das mulheres, que alcança, em suas pesquisas, dimensão inovadora também pela leitura de M. Bakhtin e seus aportes 
para a compreensão de identidades em conflito na obra Sociedade e cultura na França moderna (1975). Entusiastas admiradores de Davis, os autores reservam a esta autora um lugar destacado no colégio invisível dos historiadores da cultura, vistos em perspectiva européia.

Da historiografia vinculada aos Analles, sobressai no percurso a valorização de Os reis taumaturgos (1924), de Marc Bloch, na medida em que lhe é atribuído o papel de antecessor dos estudos de cultura, conceito que seria progressivamente dilatado em decorrência das relações estabelecidas pelos historiadores entre História e Antropologia, especialmente na École des Hautes Études em Sciences Sociales (EHESS). Ao percorrer a historiografia francesa, Serna e Pons não escondem seu entusiasmo pelo impacto causado pela vida e obra de Marc Bloch, que vem sendo, nos dias atuais, cada vez mais valorizado, e pelo "atelier parisiense", no qual rastreiam a construção dos alicerces da antropologia histórica que permitiu o florescer da História cultural, desde os "pais fundadores" da Nova História até Roger Chartier, passando das mentalidades à história sociocultural.

O largo alcance territorial do colégio invisível da História cultural, pulverizado entre o Velho e o Novo Mundo, inclui também a universidade de Princeton, nos Estados Unidos, considerado o "laboratório" que acolheu Roger Chartier, Peter Burke, Natalie Z. Davis e Carlo Guinzburg, em torno da liderança de Lawrence Stone. A este coube papel destacado pela reflexão de balanço do estatuto epistemológico da História que clareou os avanços da disciplina em direção aos estudos de cultura, na qual o estilo narrativo e o viés etnográfico permitem evocar no leitor um "efeito presencial". Melhor dizendo, por tratar-se de uma História vivamente construída, sugere ter sido o historiador testemunho presencial dos fatos e interlocutor direto de seus personagens. Muito contribuiu para tal efeito o retorno da narrativa no discurso histórico, inovador porque tornado complexo com a alternância de descrição e análise que permitem configurar a cultura em perspectiva histórica, e alcançar 


\section{Teresa Malatian}

formas complexas de compreensão do passado resultantes da substituição da Sociologia e da Economia pela Etnologia, como referente dominante nas ciências sociais.

Não deixam de assinalar a figura destacada que Clifford Geertz ocupou na virada antropológica da História ao propor, em A interpretação das culturas (1987) e em O antropólogo como autor (1989), a construção de miniaturas etnográficas ricas em significado e iluminadoras de comportamentos e códigos reguladores das grandes paisagens culturais. Seu modelo interpretativo apropriado pe-

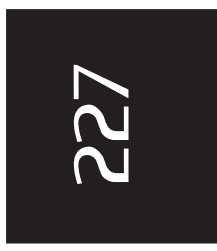
los historiadores permite a leitura da cultura como texto no qual o evento constituiria um signo, em micro-dimensão, cujo sentido está à espera de interpretação pelo observador externo, a exemplo do enfoque micro-analítico realizado por R. Darnton em $O$ grande massacre dos gatos (1984).

Com tais marcos de referência, Serna e Pons percorrem ainda as mais recentes tendências historiográficas como o linguistic turn e a virada auto-reflexiva que resulta na análise da obra histórica como objeto cultural que finaliza o longo percurso historiográfico iniciado na fundação dos Annales, e construído em conexões transnacionais.

Vale a pena salientar o aspecto didático da obra que faz dela um sólido instrumento para os praticantes do gênero. A lamentar-se, apenas, a ausência de referências ao desenvolvimento dos estudos do campo no país de origem dos autores.

Recebida em 30/01/2007. Aprovada em 08/05/2007. 